\title{
Factors Determining
}

\section{Financial Reporting On The Internet By Banks In Bahrain \\ P.L. Joshi, (E-mail: joshi@buss.uob.bh), University of Bahrain} Hasan Al-Bastaki, (E-mail: bastakih@buss.uob.bh), University of Bahrain

\begin{abstract}
A revolution in corporate reporting is about to engulf users of financial statements. As elsewhere, companies in Bahrain have started making commercial use of Internet technology by presenting financial information to the users. This paper examines the factors determining such financial reporting on the Internet by banks in Bahrain. It also surveys the current state of usage in a sample of 35 banks in Bahrain. Discriminant analysis was performed and the results indicated that size (log of total assets) is the main factor determining the financial reporting on the Internet. The type of bank, such as commercial banks with offshore business units is also another influencing factor. There is also some indication that profitability may contribute in such a decision. However, the usage of this modern technology by banks is still limited but there is every indication that the phenomenal growth of the Internet will continue. Decision-makers increasingly are using the Internet as a new source of obtaining traditional information. In this regard Petravick and Gillet (1996) state that to meet the needs of a computer sophisticated generation and to provide easy, real time access to information, high-quality financial reports will have to be an integral part of every organization's Internet presence.
\end{abstract}

\section{Introduction}

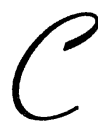

orporate reporting is the process of communicating information, both financial and non-financial relating to the resources and performance of the reporting entity (ASSC, 1975). However, the sophistication of business users of corporate information has also developed in the recent period. This change has been driven by the wider change in society and supported by a travel and communication revolution. Current technological developments, particularly those related to the Internet and

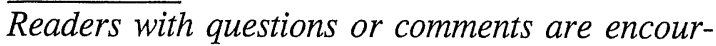
aged to contact the authors via e-mail.
World Wide Web (WWW), are providing new platforms for distributing financial information. In fact, Internet has been reckoned as a distinctive and alternative mode for distributing financial information. Because financial and management accountants are responsible for the preparation and distribution of financial information to creditors, shareholders, potential investors, and other external parties, they should be particularly interested in these developments (Petravick and Gillet, 1996). Recently, the Financial Accounting Standard Board (FASB) has started reviewing what type of information beyond the more traditional accounting and earn- 
ings statistics will make annual reports more relevant to investors. Additionally, in a move that shows FASB's awareness of the impact of the Internet on shareholder communications, a research project takes the financial statements of a fictitious company and creates a model Web site, exploring the best ways to use current technology to present financial data. These are the interesting developments taking place, in view of the fact that there are no definitive pronouncements for regulating the disclosure of financial information on the Internet.

This study attempts to provide useful descriptive and empirical information on how the banks in Bahrain voluntarily disclose their financial information on the Internet. The study also examines the relationship between the extent of financial disclosure and the main factors influencing such disclosures by banks.

The rest of the paper is organized as follows. The next section presents financial reporting environment of banks in Bahrain, followed by an examination of prior research, hypotheses development, research method employed, analysis and discussion of results. Finally, the paper concludes the findings and suggests issues for future research.

\section{Financial Reporting Environment of Banks Operating in Bahrain}

Banks and other financial institutions operating in Bahrain are supervised by the Bahrain Monetary Agency (BMA) which was created in 1973 with extensive central banking power. The Agency grants three different types of banking licenses: full commercial banks, offshore banks and investment banks. Commercial banks are allowed to offer all banking services to individuals and institutions resident in Bahrain. Offshore banks are allowed to offer banking services to non-residents of Bahrain. They are not allowed to deal with residents of Bahrain, except for the government and full commercial banks. Investment banks are permitted to accept deposits from banks inside and outside Bahrain, and to make loans and advances to non-residents.

For governing the financial reporting of banks operating in Bahrain, there are two pieces of most important legislation: the BMA Law of 1972, and Bahrain Commercial Companies' law of 1975. The Agency Law requires that bank supply information needed by the agency for supervisory and statistical purposes. Amongst the information required by the Agency are annual audited financial statements, which should be prepared according to International Accounting Standards (IAS). The Bahrain Commercial Companies Law of 1975 requires that companies, including banks incorporated in Bahrain, should prepare for each financial year, a balance sheet and profit and loss statement and an independent auditor audit these statements. However, the Law does not specify the accounting standards which should be used in preparing companies financial reports and auditing standards (AlBastaki, 1997).

\section{Disclosure on the Internet: Previous Research}

Many studies have been carried out on the extent of voluntary disclosure and attempts made to explain different levels of disclosure using company characteristics such as, size, listing status, leverage, or industry type (e.g. see, Chow and Wong-Boren (1987), Cooke (1989(a), 1989(b), 1991, 1992, 1993; Hossain, et al, 1994; Al-Bastaki, 1997²). Different theories have been used to explain voluntary disclosure. They may be relevant in the context of disclosure on the Internet. These theories include agency theory, signaling theory, and cost benefit analysis and legitimacy theory. Marston and Shrives (1996) provides a review of many of these theories.

Recently, a number of authors carried out surveys to establish the extent of Internet reporting by companies in different countries. These include Flynn and Gowthorpe (1997) who surveyed the top 100 of 'Fortune Globals' top 500 
companies, of which 89 (89\%) had a web site. Financial information reported on the Internet includes: consolidated balance sheets (52), consolidated profit and loss accounts (52), notes to accounts (39), cash flow statement (44), auditors' reports (30), reports by directors (45), and segmental information (43). Lymer (1997) surveyed the top UK companies by market capitalization, of which 46 (92\%) companies had web sites. He noted that banking/financial services and insurance companies generally gave very limited accounting information, whereas retail and pharmaceuticals gave rather better social and environmental reporting information. Lymer and Tallberg (1997) examined all 72 listed Finnish companies, out of which, $90 \%$ had web sites (90\%). Wildstrom (1997) surveyed US 'high performance' companies on the Business Week 50 list. Forty-seven had web sites. He noted that high-tech companies were generally more liable to be using the new medium. Petravick and Gillet (1996) surveyed 150 Fortune companies and they reported that of the 150 companies, 103 had World Wide Web sites, 83 of the $103(81 \%)$ make financial information available on the sites. Information disseminated by these companies falls within three categories: advertisement (3 companies), limited information (34 companies), and comprehensive information (46 companies). In the comprehensive reports available on the Web, the typical presentation includes the most recent annual report prepared in accordance with generally accepted accounting principles, independent auditor's report, and management discussion and analysis. A few of them presented their annual reports for two to four years and in some cases, the $10-\mathrm{K}$ also was available.

The study of Deller et al. (1998) analyzes the web sites of the $100 \mathrm{US}, 100 \mathrm{UK}$, and 100 German corporations representing each country's relevant stock market. 100 index (S\&P, FTSE, and DAX). The study showed that $95 \%$ of the US, $85 \%$ of the UK and $76 \%$ of the German corporations actually were presented in the Internet with a homepage. Gray and Debreceny
(1997) provided some information from a survey they conducted in December 1996 on the use of the web for reporting by the US Fortune 500 companies. They found that 49 of these companies had web sites and 34 of them had presented financial information of some sort on their web sites. Out of the 34 companies, only 18 had presented audited statements attached to the reports provided online. Marston and Leow (1998) surveyed FT-SE 100 listed companies in November 1996 and found that a total of $63(63 \%)$ companies had web sites. Of this 63,45 disclosed financial information and 11 disclosed only parts or summaries of their annual reports. Furthermore, they assessed the relationship between company characteristics and Internet disclosure. It was found that large sized companies with a web site are more likely to include financial information. The study did not find any significant relationship between industry type and disclosure of financial information.

In a recent study, Craven, and Otsmani (1999) surveyed 206 companies in U.K., and they found that 86 companies had Web sites and only $41(20 \%)$ companies disclosed social and environmental information. Their study concludes that there is a statistically significant association between companies disclosing social and environmental information on their web site and their industry group. Furthermore, a statistically significant association between companies disclosing social and environmental information on their web site and their size is also reported.

Ashbaugh et al. (1999) investigated a sample of U.S. 290 non-financial firms, out of which 253 with web sites and 37 without web sites. They found that indicated that 70 percent of firms were engaged in Internet Financial Reporting (IFR). IFR Firms engaging in IFR were larger (by total assets) and more profitable (ROA) than firms not incorporating the Internet in their financial reporting strategies. Forty two percent of the firms with web sites engaged in IFR provided a comprehensive set of financial statements i.e., balance sheet, income statement, statement 
of cash flows, notes to financial statements, and auditor reports. The study analyzed the firm's characteristics using a multivariate logit regression based on 215 firm's complete data. Four variables, namely log of total assets, ROA, Rating (a measure that benchmarks the firm's corporate reporting practices to other firms in the same industry as classified by the AIMR), and firms' percentage of equity shares held by the individual investors. The study found that firm size was the only significant explanatory variable in predicting firms that were likely to engage in IFR. The classification accuracy of the model was $65.6 \%$. Furthermore, this study found substantial variation in the quality of firms' IFR practices especially the variations in quality pertaining to the timeliness.

Hassan et al. (1999) studied the perceptions of chief financial controllers (CFC) from 247 companies which were listed with Kuala Lumpur Stock Exchange (KLSE) relating to the usefulness, vis-à-vis benefits and costs, of the reporting and disclosure of financial information on the corporate Web sites. The study reported that 89 (36\%) companies have Web sites and of this, only $41(46.1 \%)$ companies disclosed financial information on the Web sites. The study found that generally the benefits, both to the companies and users of financial information, were perceived to be greater than costs of adopting the Internet as another means of disclosing and distributing corporate financial information. In addition, the univariate tests showed that firm's size and profitability were significant factors motivating the decision to have corporate Web sites and to disclose financial information on such sites.

From a review of the above research studies, it appears that there is an interesting variation in companies' use of the Internet for financial reporting.

\section{The Hypotheses}

Agency, signaling and legitimacy theory, and cost benefit analysis, all indicate that there may be a positive relationship between size and disclosure. Ball and Foster (1982) and Firth (1979) found that if the production cost relating to certain accounting policy is high, then large firms are more likely to have resources necessary to adopt such policy. This hypothesis is consistent with many empirical disclosure studies, (see for example, Ashbaugh et al., 1999; Hassan et al., 1999; Marston and Leow, 1999; Botosan, 1997; Land and Lundholm, 1993) which have found, in most cases, that size is a significant explanatory variable. The size of a company can be measured in a number of different ways. In this study, size variable was considered, namely log of total assets. Therefore, the first hypothesis is:

Ho1: There is no significant association between company size and the extent of financial disclosure by banks on the Internet.

Lymer (1997) and Wildstrom (1997) findings suggest that there may be an industry effect on Internet disclosure by companies. This may be so because some companies have a definite public profile. This hypothesis is suggested by political process theory and signaling theory (Giner Inchausti, 1997). However, empirical findings in this context are still mixed one (Marston and Shrives, 1996). Thus, the second hypothesis is:

Ho2: There is no significant association between types of banks (industry type) and the extent of financial disclosure by banks on the Internet.

For this study, the industry type was classified into three broad categories namely, commercial banking, commercial banks with offshore banking units and offshore banking units.

Singhvi and Desai (1971) argued that higher earnings would stimulate managers to disclose more information in order to ensure investors of the firms' profitability and boost management's compensation. This view was supported through 
empirical studies by Singhvi and Desai (1971) themselves as well as by other researchers (e.g. Cerf, 1961; Malone et al. 1993). Bowman and Haire (1975) confirmed a positive relationship, while other studies have produced opposite (Hackson and Milne, 1992), confusing (Belkaoui and Karpik, 1989) and no relationships between profitability and financial disclosure (Cowan et al., 1987). However, the study by Hassan et al. (1999) indicated that higher profitable companies are more likely to disclose financial information in the Internet. On the other hand, in the study of Ashbaugh et al. (1999), profitability (ROA) was not found to be a significant variable. Based on the above evidence, the third hypothesis is:

$\mathrm{H}_{0}$ : There is no significant association between profitability and the extent of financial disclosure by banks on the Internet.

\section{Research Method}

In order to examine the extent of financial disclosure on the Internet, a sample of 49 banks was used for this study. The list of banks was collected from the Bahrain Monetary Agency (BMA). These banks were then contacted by telephone in order to collect the necessary financial data required for final analysis. However, only 35 banks agreed to provide the financial data. There were six commercial banks; eight commercials with offshore banking units and the remaining twenty-one were offshore banking units. This sample was then surveyed in December 1998 to find out whether these companies had a web site on the Internet, and if they did, further research was carried out. The companies were searched by name using the various search engines, such as Excite, Alta Vista, Infoseek, Yahoo etc. A list of banks surveyed along with their web sites is provided in Appendix II.

Both descriptive (mean and standard deviation) and inferential statistics (Discrimiant analysis) are employed in this study for analyzing data.

\section{Results and Discussion}

Descriptive data relating to types of banks, number of banks with or without Web sites, total assets etc. are presented in Table 1.

Table 1 shows the summarized results based on the survey of how companies disclose their financial information on the Internet. As of June $30,1998,22(62.9 \%)$ of the sample banks had web sites or home pages on the Internet, while 13 banks (37.1\%) had no web sites or home pages on the Internet. Of the total 22 banks that had web sites or home pages, 4 are commercial banks, 7 are commercial banks with offshore business units and 11 (50\%) are only offshore banking units. Other statistics for all the banks are presented in Table 2 .

Table 2 shows that the mean value of total assets for all banks was $\$ 13,850.6$ million and the average profits reported stood at $\$ 1,492.2$ million. The value of standard deviations in both the cases is more than the value of mean.

Table 1

Industry type and Web Sites, $\mathbf{n}=35$

\begin{tabular}{|l|lc|cc|cc|cc|}
\hline \multicolumn{1}{|c|}{ Industry type } & \multicolumn{2}{|c|}{$\begin{array}{c}\text { Banks having } \\
\text { web sites }\end{array}$} & \multicolumn{2}{c|}{$\begin{array}{c}\text { Banks having no } \\
\text { web sites }\end{array}$} & $\begin{array}{c}\text { Banks providing } \\
\text { accounts }\end{array}$ & $\begin{array}{c}\text { Average assets of } \\
\text { banks having web } \\
\text { sites }\end{array}$ \\
\hline & $\mathrm{N}$ & $\%$ & $\mathrm{~N}$ & $\%$ & $\mathrm{~N}$ & $\%$ & $\mathrm{~N}$ & $(\$ \text { million })^{*}$ \\
\hline Commercial banking & 4 & $(18.25)$ & 2 & $(14.5 \%)$ & 4 & $22.2 \%$ & 4 & 1425.76 \\
\hline $\begin{array}{l}\text { Commercial and offshore } \\
\text { banking }\end{array}$ & 7 & $(31.8 \%)$ & 1 & $(7.75 \%)$ & 5 & $27.8 \%$ & 7 & 247415.85 \\
\hline Offshore banking units & 11 & $(50.0 \%)$ & 10 & $(76.95 \%)$ & 9 & $50.0 \%$ & 11 & 7435.84 \\
\hline Total & 22 & $(62.9 \%)$ & 13 & $(37.1 \%)$ & 18 & $100.0 \%$ & 22 & 107859.49 \\
\hline
\end{tabular}


Table 2

Descriptive statistics about banks

\begin{tabular}{|l|c|c|c|}
\hline \multicolumn{1}{|c|}{ Variables } & Mean & SD & N \\
\hline Assets ( \$ million) & $13,850.6$ & $303,615.8$ & \\
\hline Profits (\$ million) & $1,492.2$ & $4,880.2$ & \\
\hline Ownership: & & & 8 \\
\hline Domestic & & & $22.9 \%$ \\
\hline Foreign & & & $77.1 \%$ \\
\hline
\end{tabular}

The highest mean value of total assets of $\$$ $247,415.85$ million is found for commercial banks with an offshore banking unit (see, Table 1). It is to be noted that a significant difference is found in the total assets among the three types of banks (Kruskal-Walis One Way ANOVA: Chi square $=8.025$; df $2 ; \mathrm{p}<0.05$ ). Classification by

Table 3 ownership of the sample banks shows that 8 (22.9\%) were local banks (domestic ownership) and $27(77.1 \%)$ were foreign banks.

The nature and types of financial information disclosed by banks in their web sites are presented in Table 3.

Financial information disclosed by banks having Web Sites

\begin{tabular}{|l|c|c|}
\hline \multicolumn{1}{|c|}{ Types of Information } & Number of banks disclosing N & \% \\
\hline Accounts: & & $72.8 \%$ \\
\hline Detailed & 16 & $9.1 \%$ \\
\hline Summary & 2 & $18.1 \%$ \\
\hline Not providing & 4 & $72.8 \%$ \\
\hline Balance sheet & 16 & $72.8 \%$ \\
\hline Income statement & 16 & $50.0 \%$ \\
\hline Cash flow statement & 11 & $50.0 \%$ \\
\hline Notes to accounts & 11 & $59.1 \%$ \\
\hline Objectives/ missions & 13 & $63.6 \%$ \\
\hline Other information e.g. segmental etc. & 14 & $W$ \\
\hline
\end{tabular}

Table 3 shows that of the 22 banks that had web sites, 18 (81.9\%) disclosed financial information on their web sites. Of the 22 banks, 16 (72.8\%) disclosed detailed annual reports, and only 2 disclosed parts or summaries of their annual reports. The remaining 4 banks made no financial information available on their Web sites, instead, they used the Web sites to advertise the promotion of products or services. In the 'detailed information' category, the company's most recent complete annual reports were available on the web. Some companies presented their annual reports for two years. This is useful for the user or the analyst who wishes to analyze the progress of the company. Apart from disclosing the full balance sheet and income statement, other financial information disclosed was: cash flow statement (11), notes to accounts (11), segmental type of information (14), and objectives and missions of banks (13). However, none of the banks disclosed either director/chairman report or auditors' report in their Web sites or home pages. A few of the banks also presented information using graphs etc.

The banks were also contacted on telephone to ask the purpose for disclosing their information on the Internet. Some of their objectives were

- Image building

- Informing their customers about their operating, and financial performance

- Attracting depositors and investors

- To reduce the time required delivering financial information

- To reduce the cost of communicating information state:

In this regard, Marston and Leow (1998) 
"By disclosing financial information on the Internet companies can gain some benefit. Thus with regard to the annual report, the company can reduce the production and distribution costs associated with the hard copy. Also the Internet can be used to provide specific information more quickly. The presentation of financial reports on the Internet may have reduced incidental requests from users, as they can access the web sites whenever they need financial statements. Furthermore, as the web is an:electronic medium, it can be used to provide more than just annual or quarterly reports. Thus non-financial data and other information can be updated at any time, thereby providing information in real time. The most common type of real time information is the current share price. This real time information gives an immediate advantage not provided by the historical annual reports, as it provides users with an up-to-date view of the company's performance".

It is also argued that after visiting Web sites of companies, even an unsophisticated information seeker is likely to come away feeling better informed about the whole range of a firm's activities and its financial performance.

\section{Discriminant Analysis}

Statistical analysis was also performed using Multiple Discriminant Analysis techniques to determine which variables discriminate the most among the banks in disclosing their financial statements on the Internet. Five variables namely, $\log$ of total assets; return on assets, ownership, and auditor (BIG5) and types of banks (banks with commercial operations, banks with commercial and offshore units, and offshore banking units) were included in the Discriminant analysis. Since the dependent variable (web sites) were in 'yes' and 'no' form, Discriminate analysis was used in this study. Ownership of banks (domestic and foreign), auditor type (BIG5 versus non-BIG5) and type of banks were included in the model as dummy variables. The three hypotheses explained previously are

Results were computed using STATISTICA package. Results are presented in

Ho1: There is no significant association between banks' size and the extent of financial disclosure by banks on the Internet.

Ho2: There is no significant association between industry type and the extent of financial disclosure by banks on the Internet.

Ho3: There is no significant association between profitability and the extent of financial disclosure by banks on the Internet.

Results were computed using STATISTICA software package. Results are presented in Tables 4,5 and 6 .

Table 4

Discriminant function analysis

\begin{tabular}{|l|c|c|c|}
\hline \multicolumn{1}{|c|}{ Variable } & Wilk's Lambda & F- remove & -level \\
\hline Log of assets (SIZE) & 0.922 & 6.173 & 0.018 \\
\hline Profitability & 0.841 & 2.939 & 0.096 \\
\hline Industry type (OBU) & 0.826 & 2.333 & 0.130 \\
\hline Wilk's Lambda $=0.769 ; \mathrm{F}=3(31) 3.104 ; \mathrm{p}<0.05$ & \\
\hline Canonical $\mathrm{R}=0.480 ;$ Chi squared $=8.272 ; \mathrm{df} 3(31) ; \mathrm{p}<0.05$ & \\
\hline
\end{tabular}

Table 5

Standardized canonical coefficient

\begin{tabular}{|l|c|}
\hline \multicolumn{1}{|c|}{ Variable } & Root 1 \\
\hline Log of assets (SIZE) & 1.028 \\
\hline Industry type (OBU) & -0.554 \\
\hline Profitability & -0.740 \\
\hline Eigen value & 0.300 \\
\hline
\end{tabular}

Table 6

Classification matrix

\begin{tabular}{|l|c|c|c|}
\hline Group & $\begin{array}{c}\text { Correctly } \\
\text { classified \% }\end{array}$ & $\begin{array}{c}\text { Group I } \\
(\mathbf{p}=\mathbf{0 . 3 7})\end{array}$ & $\begin{array}{c}\text { Group II } \\
(\mathbf{p}=\mathbf{0 . 6 3 )}\end{array}$ \\
\hline Group I & 53.84 & 7 & 6 \\
\hline Group II & 95.45 & 1 & 21 \\
\hline Total & 80.00 & 8 & 27 \\
\hline
\end{tabular}


An examination of the results (Table 4) shows that log of total assets turned out to be a significant $(\mathrm{p}<0.05)$ variable in determining the disclosure of financial information on the Internet by banks in Bahrain. Thus, the null hypothesis that banks' size has no association with web sites and financial disclosure is rejected, while, the two other hypotheses related to profitability and industry type cannot be rejected. However, the overall discriminant function is found to be significant (Chi squared $=8.272$; df $=3(31)$; $\mathrm{p}<0.05$ ). The Canonical $\mathrm{R}$ is 0.480 ( $\mathrm{R}$ squared $=0.231$ ).

The values of standardized canonical coefficients for the discriminating variables are presented in Table 5. Results indicate that $\log$ of total assets, offshore banking unit, and profitability are variables, in the order of importance, which discriminate the most for banks to present their financial statements on the Internet. The eigen value is worked out to be 0.30 . Table 6 shows the classification matrix. Results indicate that the discriminating model correctly classifies the cases up to $80 \%$, indicating thereby a reliable predictive model.

\section{Conclusions}

This study was carried out to determine the extent of disclosure of financial information on Internet by banks in Bahrain and also the variables influencing such decisions of the banks. The study concludes that about $63 \%$ of sample banks had their web sites or home pages on the Internet and about $82 \%$ of them had presented their accounts on the web site mostly in detailed form. Further, it is concluded that large size banks are more prepared to disclose their financial information on the Internet. This supports the earlier findings of Marston and Leow (1998), Ashbaugh et al. (1999) and Hassan et al. (1999) (see, Appendix I) However, it seems that industry type (OBU) and profitability are also important variables for banks' decision to present their financial information on the Internet.

\section{Direction for Future Research}

Considering the fact that there is going to be a rapid growth of customers attached to the Internet, voluntary disclosure on the Internet is bound to increase. Banks are already using the Internet to publish their financial information aimed at an audience, which is much wider. This is going to raise certain glaring issues and concerns relating to regulation and liability risks of stakeholders. Verifiability of information is a concern for investors and other stakeholders. In a deregulated environment, comparability is always difficult to achieve (Gowthorpe and Flynn, 1997).

Now it is also being realized that Web, as a medium for financial statements audit reports, offers a host of potential security questions that could affect a world-wide population of thirdparty users. In a survey of CPA Society's of Accounting and Assurance Services Network, (Stevens, 1999) revealed a concern with potential security problems that could occur and also indicated that most respondents believe a CPA should be responsible for the financial information covered by a report that is published electronically. They also believe American Institute of Certified Public Accountants (AICPA) should develop standard for such financial statements. In an attempt to deal with these issues, AICPA's Auditing Standards Board (ASB) has organized the establishment of Electronic Dissemination of Audited Financial Information Task. This body was formed to consider an accountant's obligation for the electronic version of information attested to and other associated information.

Thus, there are auditing implications of Internet technology for authentication of electronic transactions. For example, Ashbaugh et al. (1999) argued unaudited financial information has the potential to shift risk from the firm to information consumers if the firm disseminates information that misrepresents the operating performance or financial position of the firm. Given the rapidity of adoption of Internet tech- 
nologies by companies and banks and the growing importance of these technologies for commerce, there is an urgent need for academic research to address the potential impacts of this technology on the audit function and disclosure of financial information on the Internet.

\section{Endnotes}

1. The ideal presentation of financial information on the Internet begins by offering links to the home page. (The home page is the primary screen that provides guidance to anyone visiting the web site). Each page of a web site or home page is identified by a unique address known as a uniform resource locator (URL). Most information on the Internet appears on the screen in a different lettering and color known as hypertext.

2. The Internet is an international collection of more than 50,000 independent communication networks that are owned by a variety of public, educational and government entities. These networks are linked to each other, creating a global web like communications system. Information passes easily among them because all connected networks use a common communication protocol. This process works so well that the Internet functions as though it were one large computer.

3. Al-Bastaki, 1997) studied disclosure practices of 20 banks in Bahrain. His study reported that disclosures in the annual reports of banks were limited. Size (total assets) of banks was found only to be positively related to the level of annual reports' disclosure. However, profitability, leverage and stock market listing were not found to be significantly associated with the disclosure level.

\section{References}

1. Ashbaug, H. Johnstone, K.M. and Warfield, T.D, "Corporate Reporting on the Internet," Accounting Horizon, Vol. 13, No 3, pp. 241-257, 1999.
2. Al-Bastaki, H, "Extent of Disclosure in the Annual Reports of Banks Operating in Bahrain," Arab Journal of Administrative Sciences, Vol. 5, No. 1, pp. 241-268, 1997.

3. ASSC, The Corporate Report: Discussion Paper, Accounting Standards Steering Committee, London, 1975.

4. Ball, R. and Foster, G. "Corporate Financial Reporting: A Methodological Review of Empirical Research," Journal of Accounting Research, Supplement, pp. 161-234, 1982.

5. Belkaoui, A. and Karpik, P.G. "Determinants of Corporate Decision to Disclose Social Information," Accounting, Auditing, and Accountability Journal, Vol. 2, No. 1, pp. 36-51, 1989.

6. Botosan, C. "Disclosure Level and the Cost of Equity Capital," The Accounting Review, Vol. 74, pp. 323-349, 1997.

7. Bowman, E.H. and Haire, M. "A Strategic Posture Toward Corporate Social Responsibility," California Management Review, Vol. 18, pp. 49-58, 197.

8. Cerf, A.R. Corporate Reporting and Investment Decisions, The University of California Press, Berkeley California, 1961.

9. Chow, C.W. and Wong-Boren, A. "Voluntary Financial Disclosure by Mexican Corporations," The Accounting Review, Vol. 62, No. 3, pp. 533-541, 1987.

10. Cooke, T.E. "Disclosure in the Corporate Annual Reports of Swedish Companies," Accounting and Business Research, Vol. 19, No. 74, pp. 113-124, 1989a.

11. Cooke, T.E. "Voluntary Corporate Disclosure by Swedish Companies, Journal of International Financial Management and Accounting, Vol. 1, No. 2, pp. 171-195, 1989b.

12. Cooke, T.E. "An Assessment of voluntary Disclosure in the Annual Reports of Japanese Corporations, " International Journal of Accounting, Vol. 26, pp. 174-189, 1991.

13. Cooke, T.E. "The Impact of Size, Stock Market Listing and Industry Type on Disclosure in Annual Reports of Japanese Listed Corporations," Accounting and Busi- 
ness Research, Vol. 22, No. 87, pp. 229237, 1992.

14. Cooke, T.E. "Disclosure in Japanese Corporate Annual Reports," Journal of Business Finance and Accounting, Vol. 20, No. 4, pp. 521-535, 1993.

15. Cowan, S.S. Ferreri, L.B., and Parkar, L.D. "The Impact of Corporate Characteristics on Social Responsibility Disclosure: A Typology and Frequency Based Analysis," Accounting, Organization and Society, Vol. 12, No. 2, pp. 111-122, 1987.

16. Craven, B. M. and Otsmani, B. "Social and Environmental Reporting on the Internet by Leading UK Companies," A Paper Presented in the $22^{\text {nd }}$ Annual congress of EAA, Bordeaux, May 5-7, France, 1999.

17. Firth, M. "The Impact of Size, Stock Market Listing and Auditors on Voluntary Disclosure in Corporate Annual Reports," $A c$ counting and Business Research, pp. 273280, 1979.

18. Flynn, G. and Gowthorpe, C. "Volunteering Financial Data on the World Wide Web. A study of Financial Reporting from a Stakeholder Perspective," First Financial Reporting and Business Communication Conference, Cardiff, 1997.

19. Giner Inchausti, B. "The Influence of Company Characteristics and Accounting Regulation on Information Disclosed by Spanish Firms," The European Accounting Review, Vol. 6, No. 1, pp. 45-68, 1997.

20. Gowthorpe, C. and Flynn, G. "Reporting on the Internet: The State of the Art," $A c$ countancy, August, 1997.

21. Gray, S.J. and Roberts, C.B. "Voluntary Information Disclosure and the British Multinationals: Corporate Perceptions of Costs and Benefits", in Hopwood, A. (ed). International Pressures for Accounting Change, Prentice-Hall International, Hemel Hempstead, pp. 116-139, 1989.

22. Gray, G.L. and Debreceny, R. "The Impact of the Internet on Traditional Assurance Services and Opportunities for New Assurance Service: Challenges and Research Op- portunities," www.summa.org.uk/SUMMA /corp/papers/papers.htm1, 1997.

23. Hassan, S. Jaffar, N., and Johl, S.K. "Financial Reporting on the Internet by Malaysian Companies: Perceptions and Practices," Asia-Pacific Journal of Accounting, Vol. 6, No. 2, pp. 299-319, 1999.

24. Hossain, M. Tan, L.M. and Adams, M. "Voluntary Disclosure in an Emerging Capital Market: Some Empirical Evidence from Companies Listed on the Kuala Lumpur Stock Exchange," The International Journal of Accounting, Vol. 29, pp. 334-351, 1994.

25. Lang, M. and Lundholm, R. "Crosssectional Determinants of Analysts Ratings of Corporate Disclosures," Journal of Accounting Research, Vol. 31, (Autumn), pp. 246-271, 1993.

26. Lymer, A. "Corporate Reporting via the Internet - A Survey of Current Usage in the UK and Discussion of Issues," First Financial Reporting and Business Communication Conference, Cardiff, 1997.

27. Lymer, A. and Tallberg, A. "Corporate Reporting and the Internet - A Survey and Commentary on the Use of the WWW in Corporate Reporting in the UK and Finland," A Paper Presented at EAA, Graz, Austria, 1997.

28. Marston, C. Investor Relations: Meeting the Analysts, Research Committee of the Institute of Chartered Accountants of Scotland, 1996.

29. Marston, C. and Leow, C.Y. "Financial reporting on the Internet by Leading UK Companies," A Paper Presented at the 21st Annual Congress of the EAA, Antwerp, Belgium, 1998.

30. Marston, C.L. and Shrives, P.J. "The Use of Disclosure Indices in Accounting Research: A Review Article," British Accounting Review, Vol. 23, p. 195-210, 1991.

31. Marston, C.L. and Shrives, P.J "A Review of the Development and Use of Explanatory Models in Financial Disclosure Studies," A paper Presented at the EAA Congress, Bergen, Norway, 1996. 
32. Malone, D. Fries, C. and Jones, T. "An Empirical Investigation of the Extent of Corporate Financial Disclosure in the Oil and Gas Industry," Journal of Accounting, Auditing and Finance, Vol. 8 (Summer), pp. 249-273, 1993.

33. Petravick, S. and Gillet, J. "Financial Reporting on the World Wide Web," Management Accounting (USA), July, (http:// pro quest.umi.com/pqdweb?TS $=9365976$, 1996. $\because$
34. Singhvi, S. and Desai, H. "An Empirical Analysis of the Quality of Corporate Financial Disclosure," The Accounting Review, Vol. 46, pp. 129-138, 1971.

35. Stevens, M.G. "Financial Information is Flooding the Internet," The Practical Accountant, February, and http://proqest.umi. com/pqdweb?TS =9299, 1999.

36. Wildstrom, S.H. "Surfing for Annual Reports," Business Week, April, 1997.

Appendix I

Overview of studies on factors determining the Internet disclosure of financial information

\begin{tabular}{|l|l|l|l|}
\hline Study (year), Country & Subjects & Statistical Tool & Explanatory Variable \\
\hline $\begin{array}{l}\text { Marston and Leow, } \\
\text { (1998), UK }\end{array}$ & $\begin{array}{l}\text { FTSE 100, 63 companies } \\
\text { had Web sites. }\end{array}$ & $\begin{array}{l}\text { Non-parametric } \\
\text { (Kruskal-Wallis test) }\end{array}$ & Market value (size) \\
\hline $\begin{array}{l}\text { Craven and Otsmani } \\
\text { (1999), UK }\end{array}$ & $\begin{array}{l}\text { 206 companies, 86 had } \\
\text { Web sites, but only 41 } \\
\text { companies provided so- } \\
\text { cial and environmental } \\
\text { information. }\end{array}$ & $\begin{array}{l}\text { Non-parametric } \\
\text { (Kruskal-Wallis test) }\end{array}$ & $\begin{array}{l}\text { Total assets/no. of em- } \\
\text { ployees/turnover (size) } \\
\text { and industry group. }\end{array}$ \\
\hline $\begin{array}{l}\text { Asbaugh et al. (1999), } \\
\text { USA }\end{array}$ & $\begin{array}{l}290 \text { manufacturing firms, } \\
247 \text { companies had Web } \\
\text { sites. }\end{array}$ & Logit Regression & Log of total assets (size). \\
\hline $\begin{array}{l}\text { Hassan et al. (1999), } \\
\text { Malaysia }\end{array}$ & $\begin{array}{l}\text { KLSE, 247 companies; } \\
89 \text { companies had Web } \\
\text { sites }\end{array}$ & Univariate test & $\begin{array}{l}\text { Total assets (size) and } \\
\text { profitability }\end{array}$ \\
\hline $\begin{array}{l}\text { Joshi and Al-Bastaki } \\
\text { (1999), Bahrain (this } \\
\text { study) }\end{array}$ & $\begin{array}{l}35 \text { banks (commercial, } \\
\text { commercial and off- } \\
\text { shore, and off-shore } \\
\text { banks), 22 banks had } \\
\text { Web sites. }\end{array}$ & Discriminant Analysis & $\begin{array}{l}\text { Log of total assets (size), } \\
\text { profitability } \\
\text { and } \\
\text { types banks are also } \\
\text { relevant factors). }\end{array}$ \\
\hline
\end{tabular}


Appendix II

List of banks included in this study

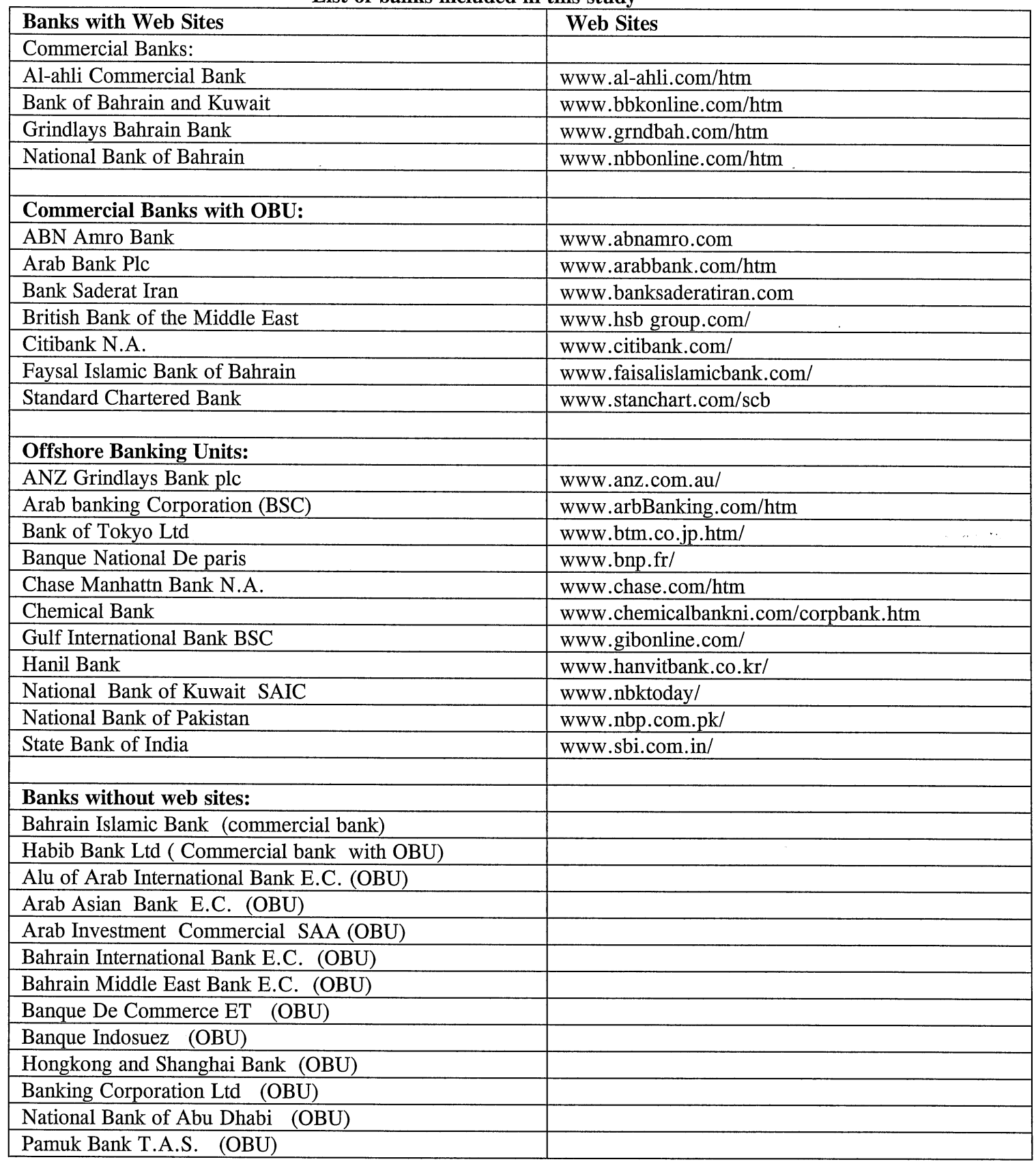

